\title{
Procedures in plastic surgery of soft tissues. From adipose tissue grafts to stem cells
}

\author{
Procedee în chirurgia plastică a ţesuturilor moi. \\ De la grefe de ţesut adipos la celule stem
}

Sorin NAE ${ }^{1}$, Laura KUHLMANN², Ion BORDEIANU³

${ }^{1}$ Şcoala Doctorală de Medicină, Facultatea de Medicină, Universitatea „Ovidius“, Constanța, România ${ }^{2}$ Centrul de Cercetare a Cancerului „Princess Margaret”, University Health Network, Ontario, Canada

${ }^{3}$ Facultatea de Medicină, Universitatea „Ovidius“, Constanța, România

\begin{abstract}
Although significant progress has been made in recent years in plastic and reconstructive surgery procedures, there are still many issues to be solved. Thus, autologous fat transplantation is one of the promising treatments for soft tissue augmentation and facial rejuvenation, due to the lack of incisional scarring and complications associated with foreign materials. However, unpredictable problems and a low rate of graft survival due to partial necrosis occur. Recent research has led to the development of new adipose tissue transplantation techniques, with promising results, without establishing a standard protocol.
\end{abstract}

Keywords: adipose tissue, stem cells, fat graft, cell-assisted lipotransfer

\begin{abstract}
- REZUMAT
Deşi în ultimii ani s-au acumulat progrese importante în procedeele utilizate în chirurgia plastică şi reparatorie, există încă multe aspecte care trebuie rezolvate. Astfel, transplantul grăsimii autologe este unul dintre tratamentele promițătoare pentru augmentarea țesuturilor moi şi întinerirea facială, datorită lipsei unei cicatrici incizionale şi complicațiilor asociate cu materialele străine. Cu toate acestea, apar probleme imprevizibile şi o rată scăzută de supraviețuire a grefei din cauza necrozei parțiale. Cercetări recente au dus la dezvoltarea unor tehnici noi de transplantare a țesutului adipos, cu rezultate promițătoare, fără a se stabili însă un protocol standard.
\end{abstract}

Cuvinte cheie: țesut adipos, celule stem, grefa de tesut adipos, lipotransfer asistat de celule stem

Grăsimea autologă este folosită în mod curent în proceduri reconstructive si estetice ca filler pentru repararea defectelor asociate țesuturilor moi. Facilitatea cu care țesutul adipos poate fi recoltat, injectat sau versatilitatea sa reprezintă câteva dintre avantajele oferite chirurgului plastician. Cu toate acestea, apar probleme imprevizibile și o rată scăzută de supraviețuire a grefei din cauza necrozei parțiale $(1,2)$.

\section{Grefarea grăsimii autologe structurale}

Grefarea grăsimii autologe este un procedeu utilizat de 120 de ani, dar interesul dezvoltării și utilizării lui în chirurgia plastică a crescut considerabil după elaborarea, la începutul anilor 1980, a tehnicii liposucției. Prezentarea în 1985 a tehnicii transplantării grăsimii autologe, în cadrul unei reuniuni a «California Society of Plastic Surgeons», ca un procedeu de mărire a sânilor a 
stârnit multe controverse. Astfel, în 1987, «American Society of Plastic and Reconstructive Surgeons Ad-Hoc Committee on New Procedures" a recomandat interzicerea acestui procedeu, deoarece majoritatea grăsimii injectate nu supraviețuiește, iar necroza celulelor conduce la formarea cicatricilor și la microcalcifieri care scad sensibilitatea mamografiei, făcând dificilă depistarea unui carcinom mamar. Ulterior, s-a recunoscut că în cazul tuturor intervențiilor chirurgicale pe sân există riscul apariției unor noduli și al unor modificări mamografice și că există posibilitatea diferențierii între calcifierile post-operatorii benigne și carcinoame (2-4). În ultimii ani, se constată o revenire a interesului pentru grefarea grăsimii autologe (5). Totuși, cunoștințele noastre privind comportamentul grefei de grăsime rămân insuficiente. $O$ înțelegere mai bună a biologiei dezvoltării, a reglării adipogenezei la nivel molecular și a supraviețuirii adipocitelor este critică pentru optimizarea tehnicii de grefare.

\section{Utilizarea fracţiei vascular stromale (Stromal Vascular Fraction - SVF) în augmentarea ţesuturilor moi}

Fracția vascular-stromală (SVF) este o populație celulară rezultată în urma manipulării țesutului adipos prin omogenizare, digestie enzimatică, centrifugare diferențială, liza hematiilor și spălare $(6,7)$.

SVF poate fi izolată fie prin excizia în bloc a grăsimii rezultate în urma operațiilor de abdominoplastie sau reducție mamară, fie din aspirate obținute prin liposucție. Majoritatea cercetătorilor separă fracția SVF din lipoaspiratele (LA) rezultate în urma operațiilor de liposucție. Dacă SVF derivă din lipoaspirate, celulele din SVF poartă numele și de celule PLA (processed lipoaspirates) $(7,8)$.

În ultimii ani, a apărut un număr crescut de publicații privind utilizarea celulelor SVF în repararea leziunilor provocate de radioterapia practicată după mastectomie (9), în augmentarea mamară (10), reconstrucția mamară după mastectomie (11), lipoatrofie facială (2) etc.

\section{Tratamente combinate: grefa de ţesut adipos + preparatele PRP (Platelet Rich Plasma) în augmentarea ţesuturilor moi}

În ultimul timp, câteva grupuri de cercetători au propus co-aplicarea grăsimii recoltate în special prin tehnica Coleman $(12,13)$ și a PRP - un rezervor natural de factori de creștere ce stimu- lează repararea și regenerarea tisulară. Adăugarea PRP la grăsime poate reprezenta o modalitate de a furniza substanțe nutritive, îmbunătățind supraviețuirea grefei de țesut adipos. Eliberarea factorilor de creștere stimulează angiogeneza, diferențierea și proliferarea celulelor, conducând la reconstituirea unei matrici tridimensionale, care permite plasarea adipocitelor într-o structură 3D.

Într-o serie de studii in vitro s-a demonstrat că PRP crește rata de supraviețuire a celulelor țesutului adipos și a diferențierii celulelor stem (14). Deși efectul PRP asupra țesutului adipos a fost studiat in vitro și pe animale model, aplicațiile clinice n-au încă suportul unor studii controlate randomizat.

\section{Utilizarea ADSC (Adipose Derived Stem Cells) în chirurgia plastică}

Fracția mononucleară a țesutului adipos, numită fracție vascular-stromală (SVF), a fost inițial descrisă ca o sursă de precursori adipocitari, activi mitotic, de către Hollenberg și Vost, în 1969 $(15,16)$. Noțiunea de celule stem derivate din țesutul adipos (ADSC) a fost recunoscută numai după 2001, când Zuk și colab. au demonstrat că SVF conține un număr mare de celule stem tipMSC (celule stem mezenchimale), ce pot suferi diferențiere la adipocite, condrocite, miocite și osteoblaste (6).

În prezent, este unanim recunoscut că celulele ADSC pot fi ușor extrase din țesutul adipos, sunt capabile de expansiune in vitro, au capacitatea de a se diferenția în multile tipuri celulare și pot fi utilizate în medicina regenerativă (1720). Deja au fost publicate studii clinice, dintre care unele au demonstrat succesul tratamentului cu ADSC în reconstrucția tisulară. Totuși, există încă probleme legate de dificultățile practice de extindere a protocoalelor de izolare a acestor celule la volume necesare clinic, de faptul că preparatele celulare izolate în diferite laboratoare se deosebesc prin gradul de puritate, markerii moleculari caracteristici etc. (21).

Sunt în curs de desfășurare studii clinice utilizând terapia cu ADSC, iar rezultatele lor parțiale sunt promițătoare nu numai în chirurgia plastică, dar și în alte specialități medicale. Astfel, Herreros și colab. (2012) (22) au realizat un studiu clinic randomizat în mai multe centre, pe 200 de pacienți adulți, privind implicarea celulelor ADSC autologe în managementul unor fistule anale complexe, ale cărui date parțiale demonstrează faptul că această procedură este sigură și demonstrează urgentarea procesului de ree- 
pitelizare a rănilor deschise. Este necesară standardizarea protocoalelor și realizarea unor studii randomizate mai mari care asigură siguranța aplicațiilor conform directivelor FDA (U.S. Food and Drug Administration) (23).

\section{Utilizarea tehnicii CAL (Cell Assisted Lipotransfer) de grefare a ţestutului adipos îmbogătit în celule ADSC conduce la rezultate clinice satisfăcătoare}

Principalele probleme raportate în cazul grefării grăsimii autologe sunt resorbția parțială a grefei, implicând necesitatea repetării procedurii chirurgicale, precum și necroza parțială a țesutului adipos transplantat cu apariția chisturilor și a microcalcificărilor $(2,24)$.

Țesutul adipos (AT) implantat supraviețuiește printr-un mecanism de simplă difuzie până este restabilită circulația sangvină. Astfel, supraviețuirea grefei, în particular în cazul unui volum mare grefat, este rezultatul unui echilibru între acest proces și moartea celulară indusă de hipoxie (25). Factorii care favorizează supraviețuirea celulară induc retenția pe termen lung și, prin urmare, durata de viață a grefei.

Pentru a depăși inconvenientele practice ale grefării gasimii prin lipoinjecție, s-a dezvoltat o nouă strategie numită lipotransfer asistat de celule (CAL - Cell Assisted Lipotransfer), în care au fost utilizate celulele ADSC autologe în combinație cu grefa de țesut adipos. Mulți autori n-au utilizat celulele ADSC purificate in vitro, ci fracția SVF proaspăt izolată, care este o populație heterogenă de celule, îmbogățită în ADSC $[2,26]$.

Rapoartele publicate în ultimii zece ani nu au atins însă un consens privind superioritatea tehnicii CAL față de tehnica transplantării grăsimii autologe (AFT). În raportul lor retrospectiv, Toyserkani și colaboratorii (24) au concluzionat că majoritatea procedurilor CAL prezentate în literatura de specialitate par să favorizeze suplimentarea țesutului adipos transplantat cu celule ADSC. Autorii atrag însă atenția asupra faptului că studiile viitoare necesită o mai bună standardizare a modului de raportare, care să permită: (i) o evaluare obiectivă a rezultatelor clinice observate, precum și (ii) identificarea potențialelor riscuri asociate acestei noi proceduri (24).

Este important de amintit că și tehnica grefării țesutului adipos autolog a fost întâmpinată cu reticență la momentul introducerii sale. Resorbția și necroza țesutului adipos transplantat reprezintă două dintre complicațiile asociate tehnicii clasice de grefare a țesutului adipos autolog. Se cunoaște faptul că formarea unei vascularizații funcționale guvernează supraviețuirea țesutului adipos matur (27). Prin suplimentarea grăsimii transplantate cu celule ADSC, ce rezidă în țesutul adipos între adipocite sau în matricea extracelulară (28), tehnica CAL permite protejarea adipocitelor mature de hipoxie.

Atât fracția vascular stromală (SVF) îmbogățită în celule stem, cât și celulele ADSC izolate din grăsimea autologă pot fi suplimentate țesutului adipos transplantat. Este important de menționat că lipoaspiraratele de volum mare ( $500 \mathrm{ml})$ conțin un număr suficient de celule ADSC, astfel încât amplificarea lor in vitro nu este necesară (29). Prin eliminarea etapei intermediare de amplificare a ADSC se evită obiecțiile de natură etică, precum și potențiale complicații imunologice (24), iar, în același timp, costul și durata procedeului chirurgical sunt de asemenea reduse, spre beneficiul pacienților. Din aceste motive, utilizarea fracției SVF este cel mai adesea preferată în procedura CAL.

În prezent, literatura de specialitate oferă atât exemple care susțin superioritatea procedurii CAL comparativ cu tehnica grefării țesutului adipos autolog, cât și exemple în care suplimentarea grăsimii transplantate cu celule stem ADSC nu a condus la rezultate semnificativ superioare față de metoda clasică de transplantare.

Riordan și colab. (2009) (30) consideră că procedeul CAL cu fracția SVF conduce la cele mai bune rezultate în chirurgia plastică, deoarece conține atât celule ADSC, care pot fi diferențiate în țesut adipos matur, cât și alte tipuri celulare care induc angiogeneza și au efecte imunomodulatoare. În plus, fracția SVF este și o sursă de factori solubili care facilitează procesul de vindecare a rănilor (30).

Toyserkani și colaboratorii (2016) (24) au rezumat observațiile a șapte studii clinice realizate care au comparat tehnica CAL cu procedura clasică de grefare a țesutului adipos autolog. Șase din cele șapte studii analizate au susținut superioritatea tehnicii CAL, deși modul de control, raportare sau evaluare statistică a studiilor nu este în general satisfăcător (24). Cinci dintre studiile realizate au optat pentru suplimentarea grăsimii injectate cu fracția SVF; două dintre aceste studii au raportat cazuri de augmentare mamară, în timp ce restul studiilor s-au concentrat asupra procedurilor estetice efectuate la nivelul feței. În majoritatea cazurilor, supraviețuirea grefei de grăsime în urma procedurii CAL a fost superioară celei observate în cazul transplantului clasic de țesut adipos autolog, chiar 
dacă diferența observată a fost modestă (24). Studiile clinice raportate nu au inclus în general rapoarte histologice ale grefei de grăsime posttransplant. Studii preclinice efectuate pe animale sugerează că, în general, procedura CAL conduce la formarea unui număr mai redus de chisturi, la maturarea unui număr mai mare de adipocite, precum și la formarea unei vascularizații net superioare, comparativ cu transplantul clasic de țesut adipos autolog (24).

Sterodimas și colaboratorii $(2010$; 2011) (3132) au comparat de asemenea tehnica CAL cu transplantul clasic de grăsime autologă. Studiul lor din 2011 a urmărit 20 de pacienți suferind de diferite defecte de părți moi la nivel facial (32). Autorii au concluzionat că pacienții cărora li s-a transplantat grăsime îmbogățită cu ADSC au raportat un grad superior de satisfacție la 6 luni după operație comparativ cu pacienții supuși procedurii clasice. Totuși, nivelul de satisfacție la 18 luni de la finalizarea procedurii a fost similar pentru ambele loturi ale studiului efectuat (32). Autorii au admis că procedura CAL este mai scumpă comparativ cu transplantul clasic de grăsime (justificat de necesitatea utilizării de echipament medical și de laborator adițional, precum și de necesitatea angajării personalului specializat adițional), precum și faptul că procedeul de îmbogățire a grăsimii transplantate cu celule stem conduce la prelungirea procedurii chirurgicale. Cu toate acestea, luând în considerare faptul că pacienții supuși procedurii CAL au necesitat un singur transplant pentru obținerea de rezultate estetice mulțumitoare, se poate concluziona că atât costul, cât și timpul final necesar completării operației este în majoritatea cazurilor inferior procedurilor clasice (32). Deși concluziile autorilor par încurajatoare, datele prezentate nu susțin afirmațiile privind gradul superior de satisfacție al pacienților supuși procedurii CAL la 6 luni de la operație comparativ cu cei supuși procedurii clasice de grefare. În plus, autorii au încercat în mod eronat să evalueze din punct de vedere statistic diferențele între gradul de satisfacție al pacienților supuși celor două proceduri, bazându-și calculele pe gradul subiectiv de evaluare al pacienților. Este binecunoscut în literatura de specialitate că testele statistice ce evaluează semnificația unui studiu nu se pot baza pe parametri arbitrari, precum autoevaluarea gradului de satisfacție pe o scară arbitrară (33). Evaluarea statistică a volumului de grăsime resorbit sau a procentului de grăsime ce a supraviețuit transplantului prin procedee obiective (RMN, tomografie, ecogra- fie) ar fi reprezentat repere statistice superioare celor raportate în studiul publicat.

Yoshimura și colaboratorii (29) au raportat în 2010 un rezumat al unui set de studii ce au comparat tehnica CAL cu procedeul clasic de grefare a țesutului adipos autolog. Între 2003 și 2008, autorii au tratat 188 de pacienți, majoritatea (164) fiind supuși procedurilor de augmentare mamară. 26 dintre pacienți au fost supuși procedurii CAL imediat după îndepărtarea protezelor mamare preexistente (29). Un aspect important al acestor studii este reprezentat de faptul că autorii au raportat rezultate obiective, obținute prin tehnici RMN, ecografie, mamografie, adițional tehnicilor clasice de video- și fotografie pentru evaluarea pre- și post-chirurgicală. În cazurile de augmentare mamară, măsurătorile 3D realizate la 6 luni de la efectuarea transplantului au indicat că între $40 \%$ și $90 \%$ din grăsimea transplantată prin procedura CAL a supraviețuit transplantului. Creșterea finală de volum a variat între 100 și 250 ml, net sub cea observată în general în procedurile de augmentare ce folosesc implanturi de silicon. Un număr redus de paciente a dezvoltat chisturi cu dimensiuni variind între 5 și $15 \mathrm{~mm}$ (6 paciente), iar 2 paciente au prezentat calcifieri, ce au putut fi distinse ușor de țesutul adiacent. Cu toate acestea, tehnica s-a dovedit superioară din punct de vedere al aspectului final (mai natural) și al consistenței sânului (29).

Un număr redus de studii clinice a evaluat competența celulelor ADSC purificate și amplificate in vitro cotransplantate cu grăsimea autologă. Studii preclinice utilizând modele animale au oferit un prim indiciu că grefarea unui număr mai mare $\left(10^{6}-10^{7}\right.$ comparativ cu $\left.10^{5}\right)$ de celule ADSC purificate conduce la rezultate superioare pe termen scurt, deși diferențele observate între diferitele concentrații celulare devin minime pe termen lung (24).

Cu toate acestea, nu toate studiile clinice au raportat rezultate superioare când tehnica CAL a fost comparată cu lipotransferul clasic. Peltoniemi și colaboratorii au comparat efectele procedeului clasic (aplicat în cazul a 8 paciente) cu tehnica CAL (aplicată în cazul a 10 paciente) în contextul augmentării mamare (34). Evaluarea postoperatorie s-a realizat $\mathrm{cu}$ ajutorul tehnicii RMN pe o durată de 12 luni, autorii concluzionând că, deși resorbția țesutului adipos după procedura CAL este ușor redusă comparativ cu resorbția post-procedură clasică $(50 \%$ versus $54 \%)$, diferența este minoră și nesemnificativă din punct de vedere statistic (34). Cu toate aces- 
tea, studiul a utilizat un număr redus de pacienți, făcând dificilă generalizarea rezultatului.

În urma unui studiul comparativ al literaturii de specialitate, Grabin și colaboratorii (2015) (35) afirmă, de asemenea, că datele actuale nu susțin superioritatea tehnicii CAL, comparativ cu lipotransferul clasic. Autorii atrag atenția că majoritatea rapoartelor clinice utilizează un număr redus de pacienți, raportarea augmentării volumetrice este adesea făcută în mod subiectiv, iar, în plus, analiza statistică a datelor prezentate este de multe ori suboptimală. Autorii au recunoscut că, în anumite situații, evaluarea obiectivă prin tehnica RMN nu este posibilă dacă volumele de grăsime transplantată sunt prea mici pentru a se putea detecta diferențe semnificative. Autorii studiului retrospectiv au insistat așadar asupra necesității realizării unor studii clinice randomizate în modul "orb" sau „dublu-orb“ pentru a evita subiectivitatea raportării rezultatelor. În plus, este esențial ca studiile clinice viitoare să conțină un număr mai mare de pacienți precum și ca perioada de urmărire să fie de lungă durată (35).

\section{Siguranţa aplicării tehnicii CAL}

Ținând cont de faptul că studiile realizate pe modele animale au evidențiat adesea o mai bună vascularizare a grefei de grăsime în cazul suplimentării țesutului adipos cu ADSC (24), se pune așadar întrebarea dacă utilizarea tehnicii CAL în cazul pacienților care au urmat un tratament oncologic poate conduce la activarea unor metastaze latente.

Gentile și colaboratorii (2012) (36) au concluzionat că utilizarea CAL pentru augmentarea mamară în cazul pacientelor care au fost diagnosticate anterior cu carcinom mamar nu a condus la o creștere a numărului de tumori recidivante.

Totuși, Perrot și colaboratorii (2010) (37) au raportat un caz de recidivă locală a unui osteosarcom la 18 luni după efectuarea unei operații de lipofiling utilizând tehnica CAL. Pacienta în vârsta de 17 ani nu a prezentat, timp de 13 ani, nicio recidivă în urma tratamentului oncologic și chirurgical aplicat pentru îndepărtarea tumorii primare localizate la nivelul brațului. Autorii au realizat un studiu in vitro și pe șoareci, urmărind multiplicarea numărului de celule tumorale, precum și creșterea volumului tumoral în prezența și absența celulelor ADSC. Co-cultivarea celulelor tumorale cu celule ADSC a condus în primele 24 de ore la o amplificare mai rapidă a celulelor tumorale (37), deși efectul nu a fost menținut la aceeași intesitate prin prelungirea co-cultivării. Corelația dintre recidiva locală și utilizarea tehnicii CAL în acest studiu de caz pare rezonabilă. Cu toate acestea, concluziile autorilor nu sunt susținute de date experimentale solide. Autorii au încercat să justifice potențialul efect pro-tumorigenic al celulelor ADSC transplantate ca fiind rezultatul amplificării vascularizației locale (37), deși studiul efectuat nu a evaluat prin nicio metodă dacă tumorile co-transplantate cu celule ADSC sunt într-adevăr mai bine vascularizate comparativ cu cele dezvoltate în grupul de control.

\section{Concluzii şi perspective}

Studii viitoare sunt necesare pentru evaluarea cât mai obiectivă a eficienței tehnicii CAL în comparație cu lipotransferul clasic. În principal, aceste studii vor trebui să abordeze o cohortă mai mare de pacienți și să includă un grup de control și vor utiliza (unde este posibil) metode obiective de evaluare pre- și post-chirurgicale, precum RMN, tomografie, ecografie.

Aspecte care se doresc de asemenea a fi urmărite în cercetările ulterioare includ: efectul zonei donatoare și al zonei receptoare asupra procentului de grăsime ce supraviețuiește transplantului; în ce măsură vârsta pacientului afectează reușita procedurii; factorii chimici (chemokine, factori de creștere) care pot fi adăugați pentru a îmbunătăți supraviețuirea găsimii transplantate; numărul/densitatea de celule ADSC transplantate minimum necesar pentru a reduce în mod eficient resorbția grăsimii transplantate. În plus, pentru utilizarea tehnicii CAL în cazul pacienților care au urmat tratamente oncologice în trecut, sunt necesare studii care să includă o cohortă mare de pacienți atât în lotul de control, cât și în grupul de tratament, pentru a formula o opinie obiectivă privind efectele pro- sau anti-tumorigenice ale celulelor ADSC transplantate.

Conflict of interest: none declared Financial support: none declared 


\section{BIBLIOGRAFIE}

1. Coleman S.R., Saboeiro A.P. Fat Grafting to the Breast Revisited: Safety and Efficacy. Plast Reconstr Surg. 2007; 119(3):775-85.

2. Yoshimura K., Sato K., Aoi N., Kurita M., Inoue K., Suga H., Eto H., Kato H., Hirohi T., Harii K. Cell-assisted lipotransfer for facial lipoatrophy: efficacy of clinical use of adipose-derived stem cells. Dermatol Surg. 2008; 34(9):1178-85.

3. Coleman S.R. Structural fat grafts: the ideal filler? Clin Plast Surg. 2001; 28:111-9.

4. Smith P., Adams W.P. Jr., Lipschitz A.H., Chau B., Sorokin E., Rohrich R.J., Brown S.A. Autologous human fat grafting: effect of harvesting and preparation techniques on adipocyte graft survival. Plast Reconstr Surg. 2006; 117(6):1836-44.

5. Bucky L.P., Kanchwala S.K. The role of autologous fat and alternative filler in the aging face. Plast Reconstr Surg. 2007; 120(Suppl 6):89 S-97 S.

6. Zuk P.A., Zhu M., Mizuno H., Huang J., Futrell J. W., Katz A.J., Benhaim P., Lorenz H.P., Hedrick M.H. Multilineage cells from human adipose tissue: implications for cell-based therapies. Tissue Eng. 2001; 7(2):211-28.

7. Nae S., Bordeianu I., Stancioiu A.T., Antohi N. Human Adipose-Derived Stem Cells: Definition, Isolation, Tissue Engineering Applications. Rom J Morphol Embryol. 2013; 54(4):919-24.

8. Zuk P.A., Zhu M., Ashjian P., De Ugarte D.A., Huang J.I., Mizuno H., Alfonso Z.C., Fraser J.K., Benhaim P., Hedrick M.H. Human adipose tissue is a source of multipotent stem cells. Mol Biol Cell. 2002, 13 (12): 4279-95.

9. Rigotti G., Marchi A., Galie M., Baroni G., Benati D., Krampera M., Pasini A., Sbarbati A. Clinical treatment of radiotherapy tissue damage by lipoaspirate transplant: A healing process mediated by adipose-derived adult stem cells. Plast Reconstr Surg. 2007; 119(5):1409-22.

10. Yoshimura K., Sato K., Aoi N., Kurita M., Hirohi T., Harii K. Cell-assisted lipotransfer for cosmetic breast augmentation: supportive use of adipose-derived stem/ stromal cells. Aesthetic Plast Surg. 2008; 32(1):48-55.

11. Rigotti G., Marchi A., Stringhini P., Baroni G., Galie M., Molino A.M., Mercanti A., Micciolo R., Sbarbati A. Determining the oncological risk of autologous lipoaspirate grafting for post-mastectomy breast reconstruction. Aesthetic Plast Surg. 2010; 34(4):475-80.

12. Coleman S.R. Long-term survival of fat transplants: controlled demonstrations. Aesthetic Plast Surg. 1995; 19(5):421-5.

13. Coleman S.R. Facial contouring with lipostructure. Clin Plast Surg. 1997; 24:347-67.

14. Natsuko K., Minakata T., Mitsui T., Kushida S., Notodihardjo F.Z.,
Kusumoto K. Proliferation promoting effect of platelet-rich plasma on human adipose-derived stem cells and human dermal fibroblasts. Plast Reconstr Surg. 2008; 122(5):1352-60.

15. Hollenberg C.H., Vost A. Regulation of DNA synthesis in fat cells and stromal elements from rat adipose tissue. J Clin Invest. 1969; 47(11):2485-98.

16. Rangwala S.M., Lazar M.A. Transcriptional control of adipogenesis. Annu. Rev Nutr. 2000; 20:535-59.

17. Yuksel E., Choo J., Wettergreen M., Liebschner M. Challenges in soft tissue engineering. Semin Plast Surg. 2005; 19(3):261-70.

18. Stosich M.S., Mao J.J. Stem cell based soft tissue grafts for plastic and reconstructive surgeries. Sem Plast Surg. 2006; 19:251-60.

19. Schäffler A., Büchler C. Concise Review: Adipose Tissue-Derived Stromal Cells Basic and Clinical Implications for Novel Cell-Based Therapies. Stem Cells. 2007; 25(4):818-27.

20. Choi J.H., Gimble J.M., Lee K., Marra K.G., Rubin J.P., Yoo J.J., VunjakNovakovic G., Kaplan D.L. Adipose Tissue Engineering for Soft Tissue Regeneration. Tissue Eng Part B Rev. 2010; 16(4):413-26.

21. Locke M., Feisst V., Dunbar P.R. Concise Review: Human Adipose-Derived Stem Cells (ASC): Separating Promise from Clinical Need. Stem Cells. 2011; 29 (3):404-11.

22. Herreros M.D., Garcia-Arranz M., Guadalajara H., De-La-Quintana P., Garcia-Olmo D. Autologous expanded adipose-derived stem cells for the treatment of complex cryptoglandular perianal fistulas: a phase III randomized clinical trial (FATT 1: fistula Advanced Therapy Trial 1) and long-term evaluation. Dis Colon Rectum. 2012; 55(7):762-72.

23. Gir P., Oni G., Brown S.A., Mojallal A., Rohrich R.J. Human adipose stem cells: current clinical applications. Plast Reconstr Surg. 2012; 129(6):1277-90.

24. Toyserkani N.M., Jensen C.H., Sheikh S.P., Sorensen J.A. Cell-Assisted Lipotransfer Using Autologous AdiposeDerived Stromal Cells for Alleviation of Breast Cancer-Related Lymphedema. Stem Cells Transl Med. 2016; 5(7):857-9.

25. Lin K., Matsubara Y., Masuda Y., Togashi K., Ohno T., Tamura T., Toyoshima Y., Sugimachi K., Toyoda M., Marc H., Douglas A. Characterization of adipose tissue-derived cells isolated with the Celution system. Cytotherapy. 2008; 10(4):417-26.

26. Matsumoto D., Sato K., Gonda K., et al. Cell-assisted lipotransfer: supportive use of human adipose-derived cells for soft tissue augmentation with lipoinjection. Tissue Eng. 2006;12:3375-82..
27. Fukumura D., Ushiyama A., Duda D.G., Xu L., Tam J. et al. Paracrine regulation of angiogenesis and adipocyte differentiation during in vivo adipogenesis. Circ Res. 2003; 93(9):e88-e97.

28. Strawford A., Antelo F., Christiansen M., Hellerstein M.K. Adipose tissue triglyceride turnover, de novo lipogenesis, and cell proliferation in humans measured with 2H2O. Am J Physiol Endocrinol Metab. 2004; 286(4):E577-88.

29. Yoshimura K., Asano Y., Aoi, N., Kurita M., Oshima Y., Sato K., Inoue K., Suga H., Eto H., Kato H., Harii K. Progenitorenriched adipose tissue transplantation as rescue for breast implant complications. Breast J. 2010; 16(2):169-75.

30. Riordan N.H., Ichim T.E., Min W.P., Wang H., Solano F., Lara F., Alfaro M., Rodriguez J.P., Harman R.J., Patel A.N., Murphy M.P., Lee R.R., Minev B.

Non-expanded adipose stromal vascular fraction cell therapy for multiple sclerosis. J Transl Med. 2009; 7: 29.

31. Sterodimas A., De Faria J., Nicaretta B., Papadopoulos O., Papalambros E., Illouz Y.G. Cell-Assisted Lipotransfer. Aesthet Surg J. 2010; 30(1):78-82.

32. Sterodimas A., De Faria J., Nicaretta B., Boriani F. Autologous Fat Transplantation Versus Adipose-Derived Stem CellEnriched Lipografts: A Study. Aesthet Surg J. 2011; 31(6):682-93.

33. Motulsky H. Intuitive Biostatics: A Nonmathematical Guide to Numerical Thinking. Third edition. Oxford University Press; 2013

34. Peltoniemi H.H., Salmi A., Miettinen S. et al. Stem cell enrichment does not warrant a higher graft survival in lipofilling of the breast: A prospective comparative study. J Plast Reconstr Aesthet Surg S. 2013; 66:1494-503.

35. Grabin S., Antes G., Stark G.B., Motschall E., Buroh S., Lampert F.M. Cell-assisted lipotransfer - a critical appraisal of the evidence. Dtsch Ärztebl Int. 2015; 112(15):255-261.

36. Gentile P., Orlandi A., Scioli M. G., Di Pasquali C., Bocchini I., Curcio C.B., Floris M., Fiaschetti V., Floris R., Cervelli V. A Comparative Translational Study: The Combined Use of Enhanced Stromal Vascular Fraction and Platelet-Rich Plasma Improves Fat Grafting Maintenance in Breast Reconstruction. Stem Cells Transl Med. 2012; 1(4):341-51.

37. Perrot P., Rousseau J., Bouffaut A-L. et al. Safety concern between autologous fat graft mesenchymal stem cell and osteosarcoma recurrence. PLOS ONE. 2010; 5(6):e10999. 